\title{
Distribution and Release Characteristics of Phosphorus in a Reservoir in Southwest China
}

\author{
Yuanming Wang ${ }^{1}$, Kefeng $\mathrm{Li}^{1}$, Ruifeng Liang ${ }^{1}$, Shiqing Han ${ }^{2}$ and Yong $\mathrm{Li}^{1, *}$ \\ 1 State Key Laboratory of Hydraulics and Mountain River Engineering, Sichuan University, Chengdu 610065, \\ China; wangyuanming1991@126.com (Y.W.); kefengli@scu.edu.cn (K.L.); ruifengliangscu@126.com (R.L.) \\ 2 China University of Petroleum-Beijing at Karamay, Karamay 834000, China; HsqExcellent@163.com \\ * Correspondence: yongliscu@126.com
}

Received: 19 November 2018; Accepted: 16 January 2019; Published: 23 January 2019

\begin{abstract}
Dam construction changes the nutrient transport of a river system. Phosphorus is an important fundamental material in the global biochemical cycle and is always a limiting factor in the primary productivity of reservoirs. Extending the study of phosphorus in reservoirs is necessary given the dam construction in southwest China. Zipingpu Reservoir was chosen as the research site in this study. The form and distribution of phosphorus in the reservoir's surface sediments and overlying water were analyzed. The results showed that overall, the total phosphorus (TP) content of surface sediments in the Zipingpu Reservoir decreased from the tail to the front of the dam. The TP content ranged from 682.39 to $1609.06 \mathrm{mg} / \mathrm{kg}$, with an average value of $1121.08 \mathrm{mg} / \mathrm{kg}$. The TP content at some sampling points was affected by exogenous input. Inorganic phosphorus (IP) was the main form of phosphorus in surface sediments and had a proportion of $89.38 \%$. Among the forms of IP, the content of Ca-P was larger than that of O-P; Ex-P, Fe-P, and Al-P had the lowest contents. Particulate phosphorus (PP) was the main form of phosphorus in the overlying water of the Zipingpu Reservoir and was strongly affected by hydrodynamic conditions. The content of total dissolved phosphorus (TDP) in the overlying water was relatively low. To further understand the risk of phosphorus release in the surface sediments in the reservoir, the rate and flux of phosphorus exchange at the sediment-overlying water interface were investigated through laboratory experiments. The results showed that both water temperature and $\mathrm{pH}$ significantly affected the sediment release rate, but the influence of water temperature was more significant. Acidic and alkaline conditions were conducive to the release of phosphorus from sediment, while a neutral environment was not. The release rate significantly increased with increasing water temperature, and a positive linear relationship was found between these two parameters. The sediment exhibited absorption characteristics when the water temperature was extremely low and exhibited releasing characteristics at a high temperature. These results could provide a theoretical basis for the management and protection of reservoir water environments.
\end{abstract}

Keywords: phosphorus; distribution; release characteristics; reservoir; sediment; overlying water

\section{Introduction}

Dam construction changes the hydrologic and hydraulic elements of the river system, and nutrient transport is also altered. A large amount of nutrients is stored in reservoirs through biological adsorption, physical settlement, and other functions; this storage results in a decrease in nutrient output downstream of the dam [1,2]. The retention of nutrients in reservoirs can impact the total amount delivered from land to sea and change the water quality of reservoirs. Phosphorus is an important fundamental material in the global biochemical cycle and is always a limiting factor of primary productivity in reservoirs $[3,4]$. 
Phosphorus in sediment can be classified as organic or inorganic. The components of organic phosphorus (OP) are difficult to identify and isolate; thus, many studies have treated $\mathrm{OP}$ as a single form of phosphorus. Generally, inorganic phosphorus (IP) is present in the form of phosphorus bound to iron (Fe-P), aluminum (Al-P) and calcium (Ca-P), as well as in the form of exchangeable phosphorus (Ex-P), occluded $\mathrm{P}(\mathrm{O}-\mathrm{P})$, and others [5,6]. Ex-P mainly refers to phosphorus that is adsorbed to or coprecipitated with particles in the sediment, such as active clay minerals, iron oxides, manganese oxides, hydroxides, and others [7]. Among the different forms of phosphorus, Ex-P easily enters water and is then used or adsorbed by organisms. The content of Ex-P is usually not high, but this form of phosphorus is most easily used by organisms. Fe-P and Al-P can be used by aquatic organisms when present in water in certain circumstances. Fe-P is susceptible to environmental changes. Ferric ion always exists under aerobic conditions and easily combines with phosphorus to precipitate phosphate. Under anaerobic conditions, insoluble ferric hydroxide can easily convert into soluble ferric hydroxide, which increases the risk of water eutrophication. Many compounds in water can be used as extractants to dissolve Al-P from sediments [5]. Ca-P in sediments mainly exists in the form of calcium phosphate, which is poorly soluble and cannot readily be used by living creatures. However, a sufficient carbon dioxide content in the water can increase the solubility of Ca-P and promote its release. O-P, which includes some Al-P and Ca-P, is a phosphorus salt and is mainly covered by a layer of ferric oxide film. O-P is considered to be biologically unavailable and can persist for a long time [8].

Sediment plays an important role in the biogeochemical circulation of phosphorus. Sediment can accept phosphorus from overlying water and release phosphorus to overlying water. Research in Clear Lake showed that over $3500 \mathrm{t}$ of phosphorus was stored within a $10 \mathrm{~mm}$ layer of surface sediment. Every year, the exogenous input of phosphorus to Clear Lake is approximately $160 t$, and 550-700 $t$ of $P$ is involved in the inner circulation of the lake [9]. In some lakes and reservoirs in northern China, the exogenous pollution sources are well controlled. Studies have shown that phosphorus is continuously released into overlying water when sediments at the bottom of a reservoir have a sufficient phosphorus content. In this situation, endogenous phosphorus becomes an important cause of water quality deterioration [10].

Many scholars have studied the distribution and release characteristics of phosphorus in rivers, lakes and marine [7,11-13]. Some research has even been conducted in reservoirs in China, most of them concentrated in the downstream of Yangtze River, or other river basins [14,15]. Few studies on the distribution and release characteristics of phosphorus have been conducted in a reservoir in southwest China. In recent years, many hydropower projects have been planned or built in southwest China [16-18]. These reservoirs always have great water depth (i.e., over $200 \mathrm{~m}$ or even as deep as $300 \mathrm{~m}$ ) and small surface width, which make them have different distribution and release characteristics of phosphorus than other waters. To learn the distribution and release characteristics of phosphorus in reservoirs in southwest China, the Zipingpu Reservoir was chosen as the research site in this study. The form and distribution of phosphorus in the surface sediments of the reservoir were analyzed in this study, and the phosphorus content in the overlying water was measured. To further understand the risk of phosphorus release from the surface sediments in the reservoir, the rate and flux of phosphorus exchange at the sediment-overlying water interface were investigated through laboratory experiments. These results can provide a theoretical basis for the management and protection of reservoir water environments.

\section{Materials and Methods}

\subsection{Study Site}

The Zipingpu Reservoir is in the upper Min River northwest of Chengdu City. The reservoir is a water conservancy project with comprehensive benefits, such as water supply and irrigation, as well as power generation, flood control and environmental protection. The Zipingpu Reservoir, which has 
a total capacity of $11.12 \times 10^{8} \mathrm{~m}^{3}$ and a regulating capacity of $7.74 \times 10^{8} \mathrm{~m}^{3}$, is the managed water source serving the famous Dujiangyan irrigation district. The normal water level is $877 \mathrm{~m}$, and the minimum operating level is $817 \mathrm{~m}$. The Shouxi River, a tributary of the dam, joins $12 \mathrm{~km}$ upstream.

\subsection{Sample Collection}

Samples of overlying water were collected from March 2016 to February 2017 to analyze the form and distribution of phosphorus in the Zipingpu Reservoir. A self-made sampling system was used to collect the overlying water at the bottom of the reservoir [19]. The temperature, $\mathrm{pH}$, and dissolved oxygen (DO) were also measured at the same time. The overlying water samples were placed in clean polyethylene bottles and stored frozen in the laboratory.

Surface sediments of the reservoir were collected in April 2016 to analyze the form and distribution of phosphorus and in February 2017 to conduct laboratory experiments on the rate and flux of phosphorus exchange. A device for sediment sampling was used to sample the surface sediments. The first $20 \mathrm{~cm}$ sediments of the bottom were collected and then taken to the laboratory and stored frozen. The sampling points are shown in Figure 1 and Table 1.

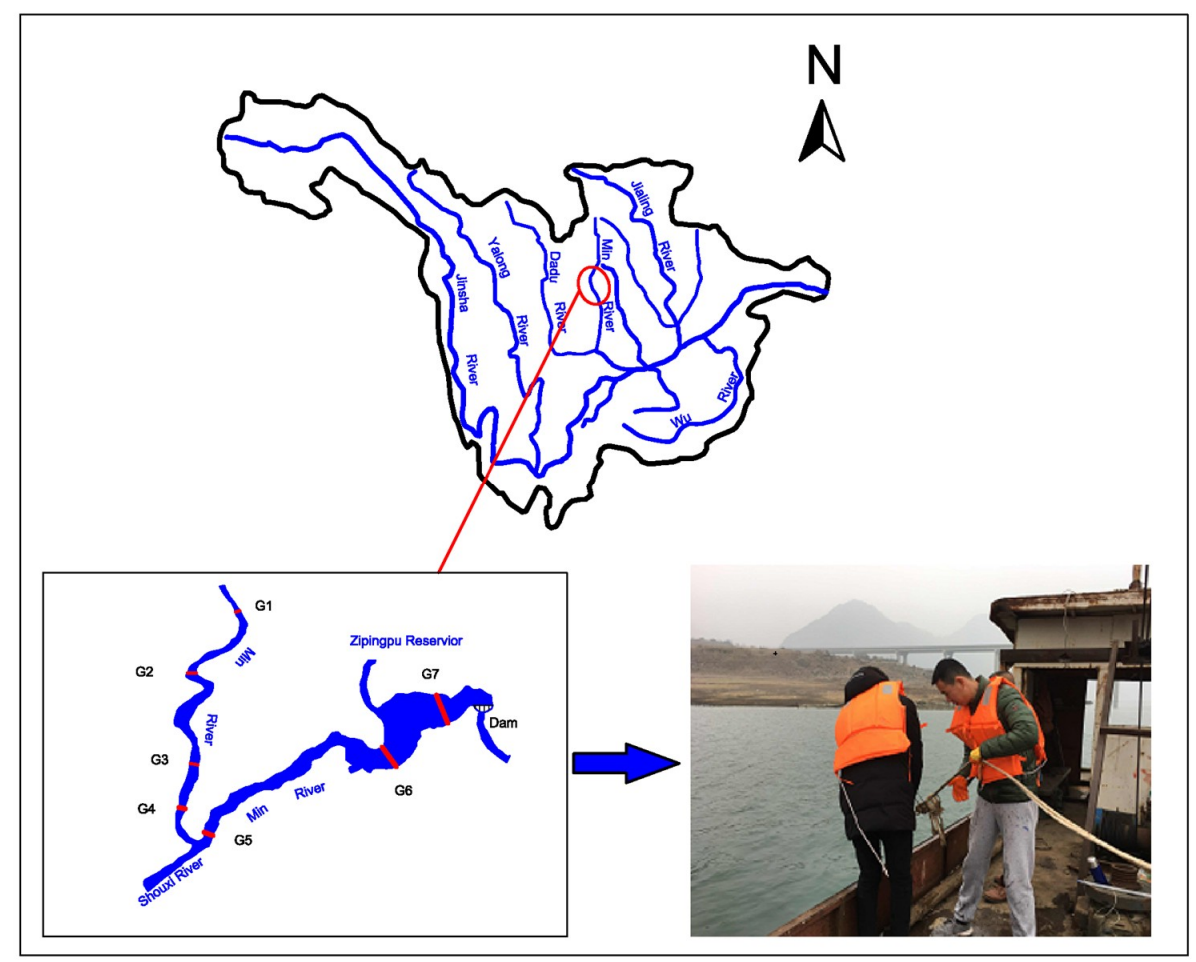

Figure 1. Location of the Zipingpu Reservoir and field sampling site.

Table 1. Detailed information on the sampling points in the Zipingpu Reservoir.

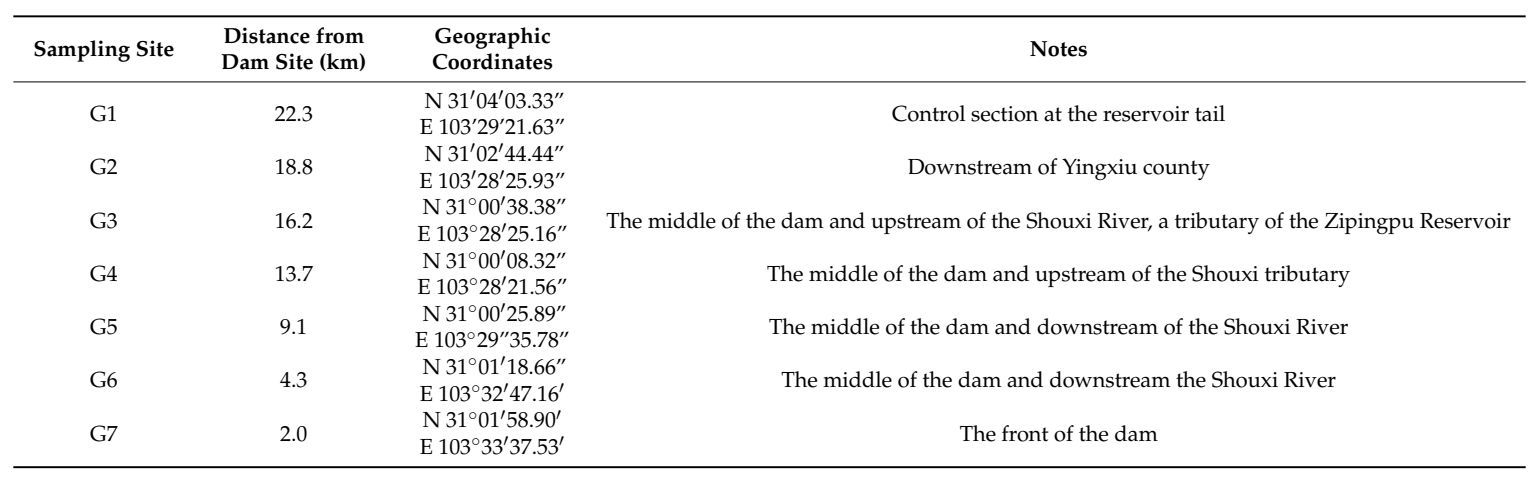




\subsection{Analysis of Overlying Water and Surface Sediments}

First, the unfiltered overlying water was digested, and then TP was measured by ammonium molybdate spectrophotometry. For the measurement of TP in surface sediments, after initial drying, the sediments were first spread on a clean plastic film and milled through a 100-mesh sieve. Stones and debris from animals and plants were removed during milling. The surface sediments were digested by concentrated sulfuric acid and perchlorate, and the TP content was determined in a molybdate-antimony-scandium color agent. Different forms of $\mathrm{P}$, including Ex-P, Al-P, Ca-P, Fe-P, $\mathrm{O}-\mathrm{P}$ and $\mathrm{OP}$, were quantified in the sediments through a sequential extraction procedure which was described by [20].

\subsection{Laboratory Experiments of the Rate and Flux of $P$}

From the reservoir tail to the dam site, the reservoir can be divided into a river section, transition section, and reservoir section. Sampling points G2, G4 and G6 represented the river section, transition section, and reservoir section, respectively, in the laboratory experiments. Laboratory experiments investigating the rate and flux of $\mathrm{P}$ considered the temperature and $\mathrm{pH}$ : five temperature levels $\left(5,9,12,15\right.$ and $\left.19^{\circ} \mathrm{C}\right)$ and three $\mathrm{pH}$ levels $(6 \pm 0.2,7 \pm 0.2$ and $8 \pm 0.2)$ were used. Considering the sampling amount of surface sediments and overlying water, and referring to previous studies, we set the water-sediment thickness ratio as 6:1 [21,22]. The experiments were conducted in an adjustable-temperature thermostatic chamber.

For each case, sediments collected from the Zipingpu Reservoir were placed in a cubic container made of glass $(25 \mathrm{~cm} \times 25 \mathrm{~cm} \times 40 \mathrm{~cm})$, and then overlying water that had been filtered through a $0.45 \mu \mathrm{m}$ membrane was slowly added into the cubic container by siphoning. The $\mathrm{pH}$ was adjusted by $\mathrm{Na}_{2} \mathrm{CO}_{3}$ and $\mathrm{HCl}$. On each day, $25 \mathrm{~mL}$ of water was collected by a pipette from $2 \mathrm{~cm}$ above the sediments and then used for TP measurements. The same volume of filtered overlying water was immediately added to the cubic container to replace the removed sample.

\subsection{Statistical Analysis}

The release rate of TP was used to describe the release characteristics in the laboratory experiment and is expressed as follows:

$$
K_{i}=\left[\left(C_{j}-C_{0}\right) V-\sum_{j=1}^{n}\left(C_{j-1}-C^{\prime}\right) V^{\prime}\right] /\left(A^{\prime} \cdot t\right)
$$

where $K_{i}$ is the release rate of TP in case $i, \mathrm{mg} /\left(\mathrm{m}^{2} \cdot \mathrm{d}\right) ; C_{j}$ and $C_{j-1}$ are the TP concentrations measured in sample $j$ and $j-1$, respectively, $\mathrm{mg} / \mathrm{L} ; C_{0}$ is the TP concentration of the overlying water at the beginning of the experiment, $\mathrm{mg} / \mathrm{L} ; \mathrm{C}^{\prime}$ is the TP concentration of the filtered overlying water, $\mathrm{mg} / \mathrm{L}$; $V$ is the volume of the overlying water, $\mathrm{L} ; V^{\prime}$ is the volume of the filtered overlying water, $\mathrm{L} ; \grave{A}$ is the area of the interface between the sediment and overlying water, $\mathrm{m}^{2}$; and $t$ is the duration of the experiment, $\mathrm{d}$.

One-way analysis of variance (ANOVA) was used to test differences in means among TP values and was followed by a post hoc multiple comparison test (least-significant difference) to determine where those differences occurred. Two-way ANOVA was performed to determine the effects of two factors and their interaction. Post hoc multiple comparisons were performed using the S-N-K test. The level of significance was set at $p<0.05$.

\section{Results}

\subsection{Spatial-Temporal Distribution of Phosphorus in Sediments}

As shown in Figure 2, the TP content in surface sediments at each sampling point ranged from $682.39-1609.06 \mathrm{mg} / \mathrm{kg}$, and the average value was $1121.08 \mathrm{mg} / \mathrm{kg}$. The TP content significantly 
decreased from the tail to the front of the Zipingpu Dam, except for points G2 and G5 (one-way ANOVA: $F=199.82, d f 1=6, d f 2=19, p<0.001)$. A linear relationship was found between the TP content and the distance from the dam site $\left(R^{2}=0.901\right)$. Inorganic phosphorous accounted for a major portion (86.5-94.5\%) of the TP at each site, and the IP content ranged from $642.12-1456.87 \mathrm{mg} / \mathrm{kg}$. The average proportion of OP relative to TP was $10.6 \%$.

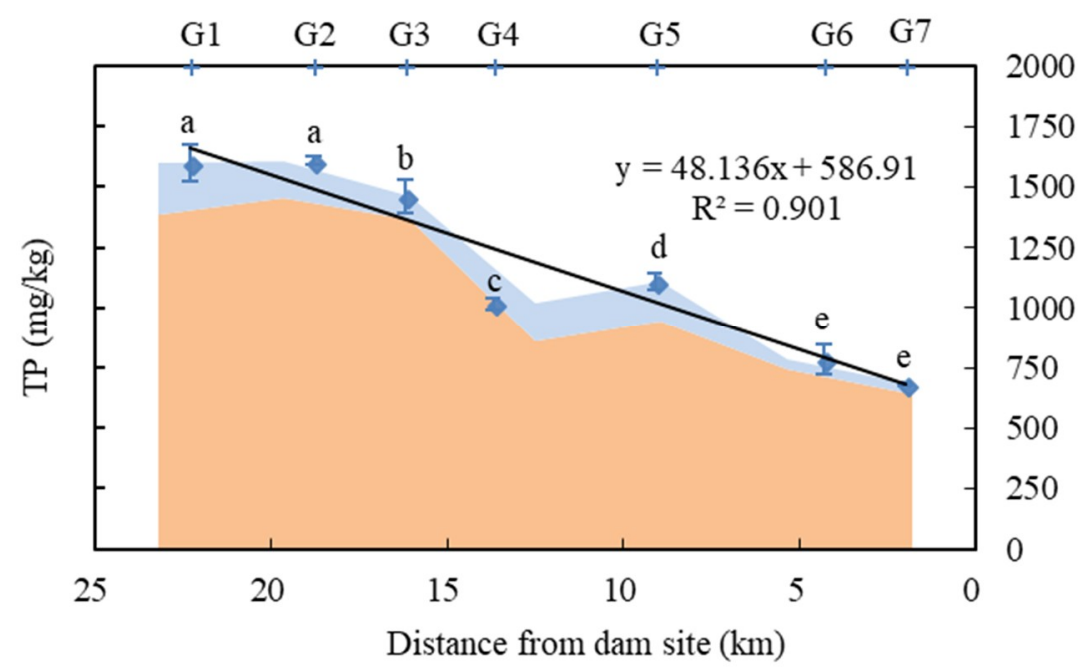

Figure 2. The concentration of phosphorus at each sampling site. The squares represent total phosphorous (TP) values, which are shown as means $\pm \mathrm{SD}(n=4)$. The letters above the squares indicate the results from a post hoc multiple comparison test (least-significant difference test); mean values that do not share a common lowercase letter are significantly different $(p<0.05)$. The area in orange represents IP, and that in light blue represents OP.

The contents of different forms of IP are shown in Table 2. Ca-P accounted for a major portion $(61.2-88.4 \%)$ of the TP at each site, and the content of Ca-P ranged from $489.09-1264.72 \mathrm{mg} / \mathrm{kg}$. The content of O-P as a proportion of TP ranked second at each site and ranged from 9.6-30.8\%. Ex-P, Al-P, and Fe-P accounted for a minority of TP at each site. Two-way ANOVA showed that both the form and the sampling site had a significant impact on the phosphorus content (Table 3). The contents at sites G4-G7 significantly differed from those at G1-G3. The contents of Ex-P, Al-P, and Fe-P were significantly smaller than the other forms of phosphorus; O-P had the next highest content, and Ca-P had the highest content.

Table 2. The contents of different forms of inorganic phosphorous (IP) at each sampling site.

\begin{tabular}{lccccccc}
\hline Sampling Site & G1 & G2 & G3 & G4 & G5 & G6 & G7 \\
\hline Ex-P (mg/kg) & 14.50 & 15.82 & 9.09 & 16.36 & 11.66 & 22.61 & 7.52 \\
Al-P (mg/kg) & 4.26 & 2.81 & 5.35 & 2.04 & 2.16 & 2.98 & 4.63 \\
Fe-P (mg/kg) & 8.68 & 7.66 & 9.22 & 12.09 & 2.34 & 7.42 & 39.51 \\
Ca-P (mg/kg) & 1223.16 & 1264.72 & 1171.02 & 638.72 & 740.04 & 489.09 & 392.80 \\
O-P (mg/kg) & 132.68 & 165.86 & 167.14 & 190.23 & 188.22 & 222.92 & 197.65 \\
\hline
\end{tabular}

Table 3. Statistical results of two-way ANOVA on the content of each type of IP.

\begin{tabular}{ccccc}
\hline Sources of Variation & df & F & Sig. & Partial Squared \\
\hline Sampling site & 6 & 10.29 & $<0.001$ & 0.638 \\
Phosphorus form & 4 & 416.78 & $<0.001$ & 0.979 \\
Sampling site * Phosphorus form & 24 & 12.85 & $<0.001$ & 0.898 \\
\hline
\end{tabular}




\subsection{Spatial-Temporal Distribution of Phosphorus in Overlying Water}

For the overlying water at the bottom of the reservoir, its TP was mainly distributed in the river section, which was more than $15 \mathrm{~km}$ away from the dam site, and the concentration ranged from $0.015-1.770 \mathrm{mg} / \mathrm{L}$ (Figure 3a). The total dissolved phosphorus (TDP) was also determined in this study: the TDP contents at most sampling points were lower than the detection limit $(0.005 \mathrm{mg} / \mathrm{L})$ in March, May, and June. Only one sample had a detectable content in April, August, and September (Figure 3b). TDP accounted for only a small part of TP (6.1\% of TP), which indicated that particulate phosphorus (PP) was the major form of phosphorus in the overlying water in the Zipingpu Reservoir (Figure 3c,d). The water temperature of the reservoir ranged from 5.8 (February) to $25.3{ }^{\circ} \mathrm{C}$ (July), and the $\mathrm{pH}$ ranged from 6.84 to 8.73 (Figure $3 \mathrm{e}, \mathrm{f}$ ). The reservoir exhibited alkaline characteristics from March to July and had a neutral environment in other months.

a
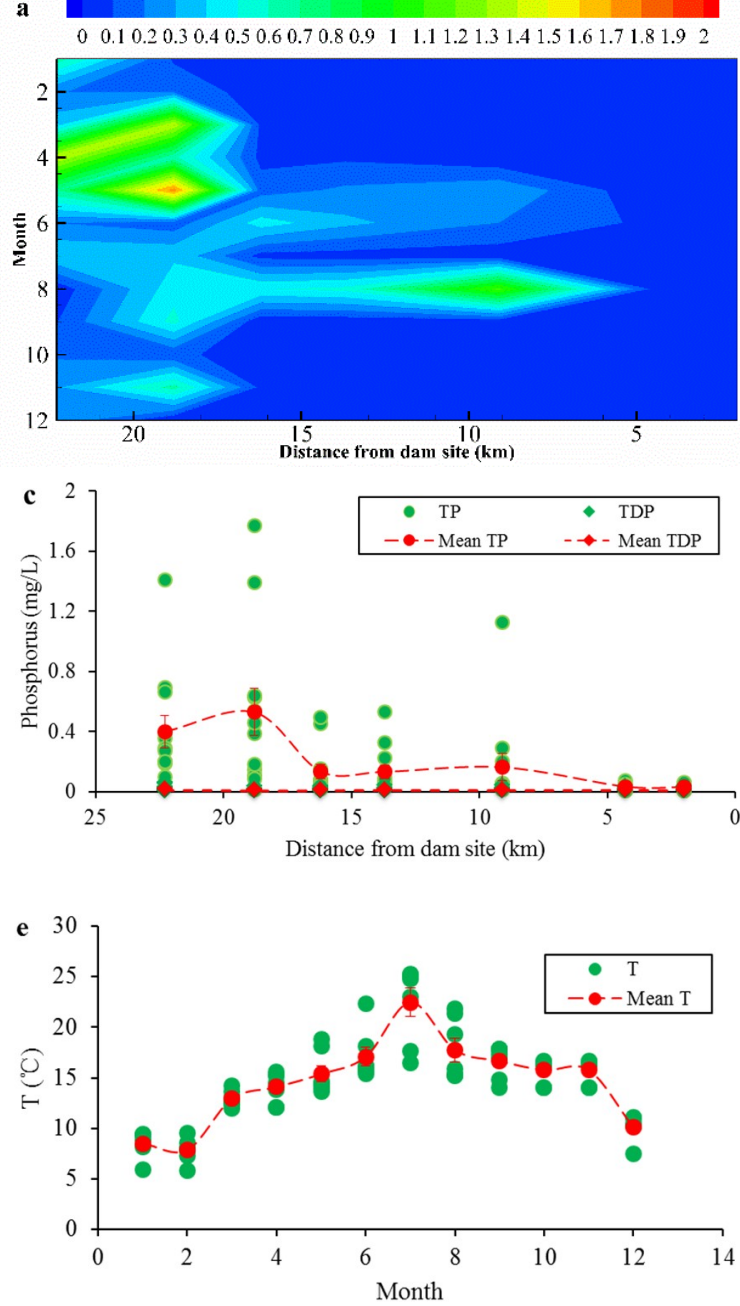
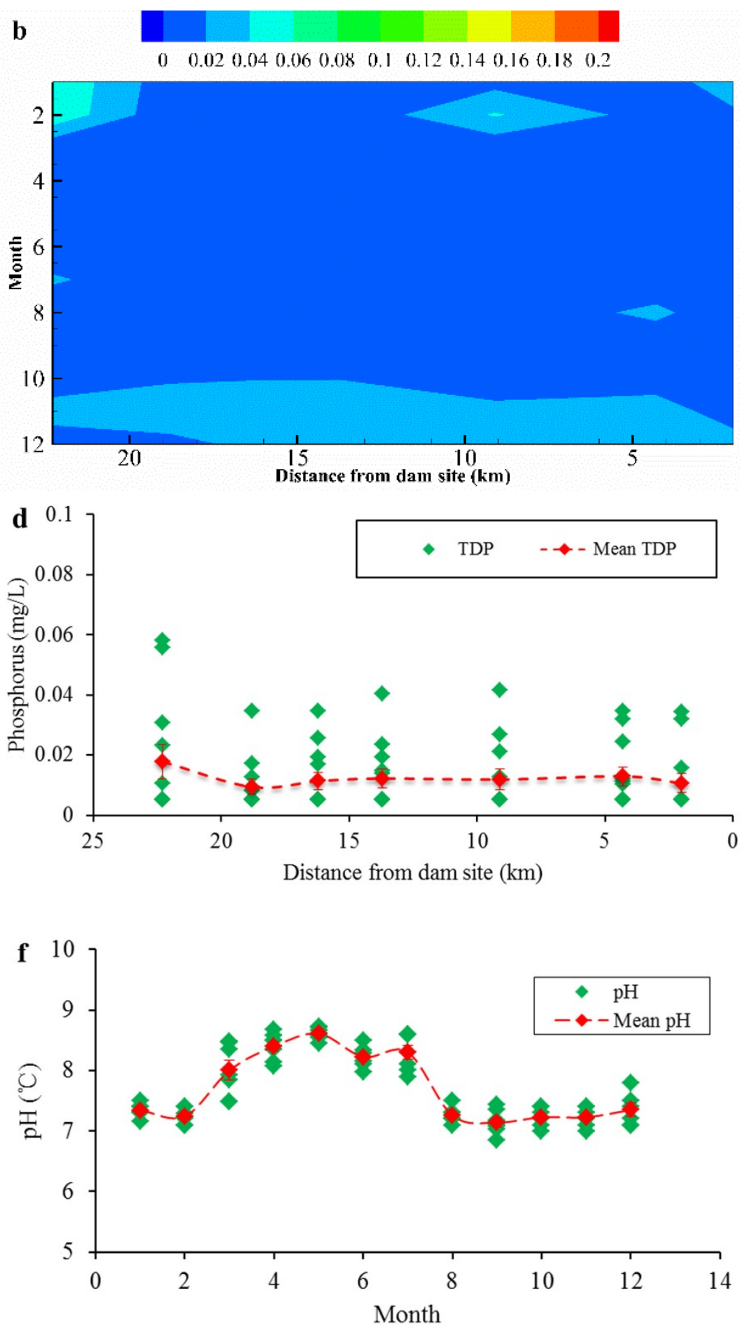

Figure 3. Environmental parameters of the overlying water in the Zipingpu Reservoir. (a) and (b) represent the spatial-temporal distribution of TP and TDP, respectively. Circles in (c) and (d) indicate TP and TDP values at different sampling sites and in different months. Circles in (e) and (f) indicate the temperature and $\mathrm{pH}$ of overlying water at different mouths. Both mean values with SE and individual values are exhibited in (c-f).

\subsection{Characteristics of Phosphorus Exchange at the Sediment-Water Interface}

Two-way ANOVA showed that the release rate of sediment was significantly affected by $\mathrm{pH}$ (Table 4), and the release rate was lower at a $\mathrm{pH}$ of $7 \pm 0.2$ than those at $\mathrm{pH} 6 \pm 0.2$ and $8 \pm 0.2$ (Figure 4), 
which indicated that acidic and alkaline conditions were conducive to the release of phosphorus from sediment, while a neutral environment was not. The impact of $\mathrm{pH}$ on phosphorus release varies with the content and form of phosphorus in the sediment $[23,24]$. Phosphorus in Fe-P and Al-P is stable under acidic conditions, while phosphorus in Ca-P is easily released when the $\mathrm{H}^{+}$concentration is high enough. Moreover, microorganisms produce $\mathrm{CO}_{2}$ in the process of organic matter degradation, which is also conducive to the release of phosphorus from Ca-P. When the $\mathrm{pH}$ of the overlying water reaches approximately $7, \mathrm{Al}^{3+}$ is hydrolyzed to colloidal $\mathrm{Al}(\mathrm{OH})_{3}$. $\mathrm{Al}(\mathrm{OH})_{3}$ has a stronger absorption capacity than $\mathrm{HPO}_{4}{ }^{2-}$ and $\mathrm{H}_{2} \mathrm{PO}_{4}{ }^{-}$. The TP content decreases with absorption by colloidal $\mathrm{Al}(\mathrm{OH})_{3}$ at a $\mathrm{pH}$ of 7. Under alkaline conditions, phosphorus release increases with the conversion of $\mathrm{OH}^{-}$ in Al-P and Fe-P to $\mathrm{H}_{2} \mathrm{PO}_{4}{ }^{-}$. In contrast, the surface of variable-charge colloids in sediments always exhibits a negative charge under alkaline conditions; thus, the absorption capacity of sediments for $\mathrm{HPO}_{4}{ }^{2-}$ in the overlying water decreases, and then an increasing TP content in the overlying water follows $[25,26]$.

Table 4. Statistical results of two-way ANOVA on the exchange rate of phosphorus at the sediment-water interface at different sections.

\begin{tabular}{cccccc}
\hline \multicolumn{2}{c}{ Sources of Variation } & df & F & Sig. & Partial Squared \\
\hline \multirow{2}{*}{ River section } & $\mathrm{pH}$ & 2 & 11.45 & 0.004 & 0.741 \\
& $\mathrm{~T}$ & 4 & 26.97 & $<0.001$ & 0.931 \\
\multirow{2}{*}{ Transition section } & $\mathrm{pH}$ & 2 & 9.43 & 0.008 & 0.702 \\
\multirow{3}{*}{ Reservoir section } & $\mathrm{T}$ & 4 & 30.92 & $<0.001$ & 0.939 \\
& $\mathrm{pH}$ & 2 & 7.94 & 0.013 & 0.665 \\
& $\mathrm{~T}$ & 4 & 30.04 & $<0.001$ & 0.939 \\
\hline
\end{tabular}

The release rate was also significantly affected by water temperature (Table 4) and significantly increased with increasing water temperature (Figure 4). A positive linear relationship was found between the release rate and water temperature in each section (Figure 4). Two-way ANOVA showed that water temperature had a more significant influence on the release rate than $\mathrm{pH}$ (Table 4). An appropriate temperature increases the microbial activity and decomposition rate of organic matter in sediments, which promotes the release of OP into overlying water. An increase in temperature weakens the mineral adsorption capacity for phosphorus, thus enabling the phosphorus in the sediments to enter the overlying water more easily [27]. Increasing temperature can also promote biological disturbance, anaerobic transformation, and mineralization, which results in a reductive state at the sediment surface and the transformation of $\mathrm{Fe}^{3+}$ to $\mathrm{Fe}^{2+}$. In this situation, phosphorus is released from iron orthophosphate and iron hydroxide, thus accelerating the release of phosphorus from sediments [28].

Under a neutral environment with a water temperature of $5{ }^{\circ} \mathrm{C}$ in the river and reservoir sections, the TP release rates of sediment were -1.33 and $-2.71 \mathrm{mg} \cdot \mathrm{m}^{-2} \cdot \mathrm{month}^{-1}$, respectively; these release rates indicated absorption characteristics and resulted in decreases in the TP concentration of the overlying water. The sediment in the reservoir section also exhibited absorption characteristics under an alkaline environment with a water temperature of $5{ }^{\circ} \mathrm{C}$. The sediment in the transition section exhibited release characteristics at different temperatures. All surface sediments were in a release state at a temperature of $9-19^{\circ} \mathrm{C}$. 


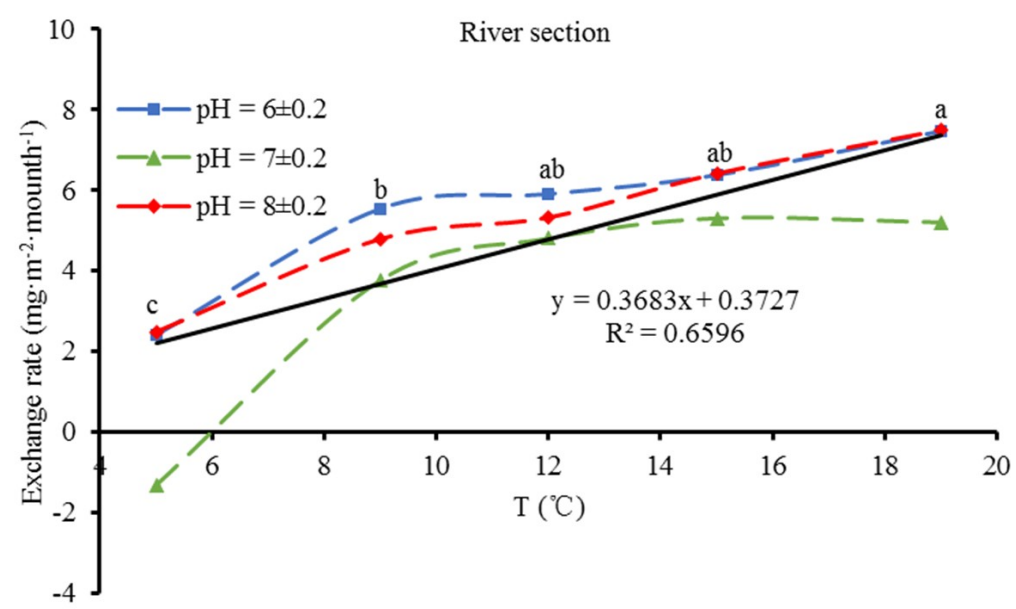

(a)

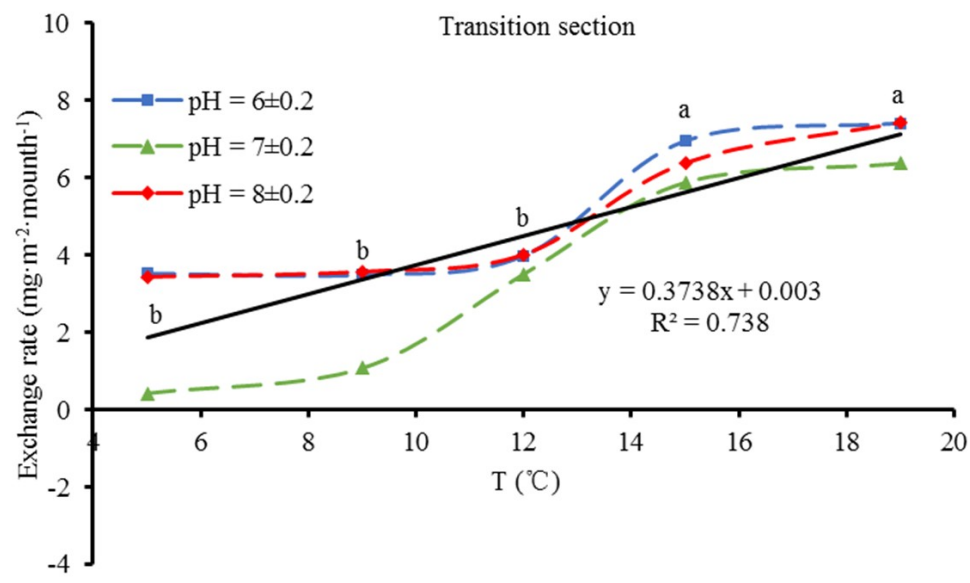

(b)

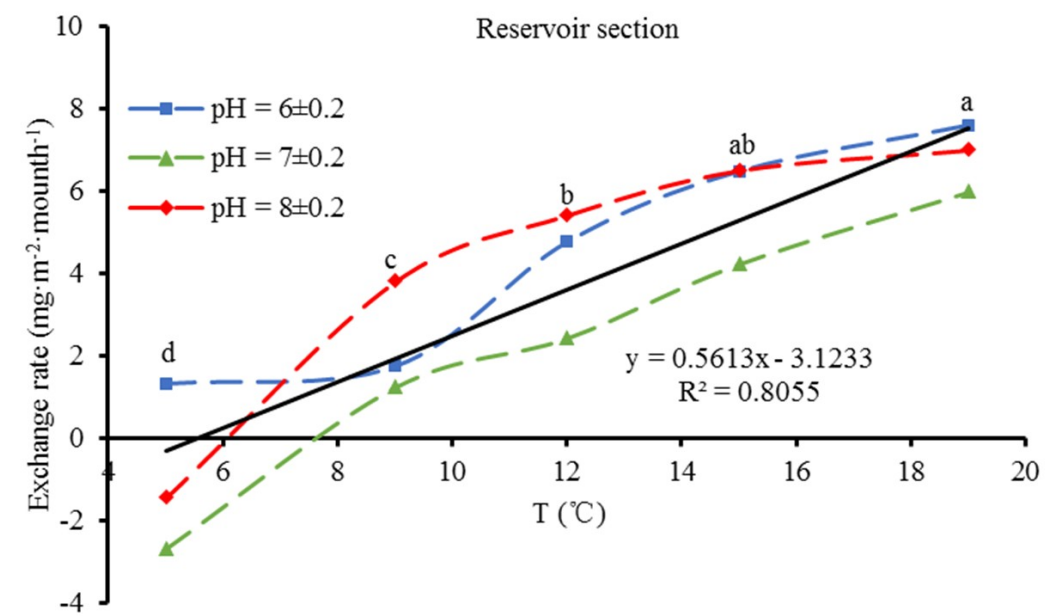

(c)

Figure 4. Exchange rate of phosphorus with varying temperature and $\mathrm{pH}$ values at different sections. Letters above the values indicate the results from a post hoc multiple comparison test (S-N-K test); values that do not share a common lowercase letter indicate a significant difference between temperatures $(p<0.05)$. 


\section{Discussion}

\subsection{Phosphorus in Sediments and Overlying Water}

Sediment is an important medium for phosphorus removal and regeneration. The endogenous phosphorus load in surface sediment weakens the water governance effect and may become significant when the exogenous phosphorus is effectively controlled. The TP of sediment has been investigated in many reservoirs and lakes (Figure 5). Compared with these previous investigations, Zipingpu Reservoir has a relatively high level of TP in surface sediment [14,29-36]. Sediment pollution can be divided into three levels according to TP content: light pollution (TP $<500 \mathrm{mg} / \mathrm{kg}$ ), moderate pollution (500 mg/kg < TP < $1300 \mathrm{mg} / \mathrm{kg}$ ), and heavy pollution (TP > $1300 \mathrm{mg} / \mathrm{kg}$ ) [37,38]. The TP content of the surface sediment in the Zipingpu Reservoir ranged from $682.39-1609.06 \mathrm{mg} / \mathrm{kg}$ and had an average value of $1121.08 \mathrm{mg} / \mathrm{kg}$. Sediment pollution at the tail of the Zipingpu Reservoir reached a high level, and at the middle and front of the dam, sediment pollution reached a moderate level.

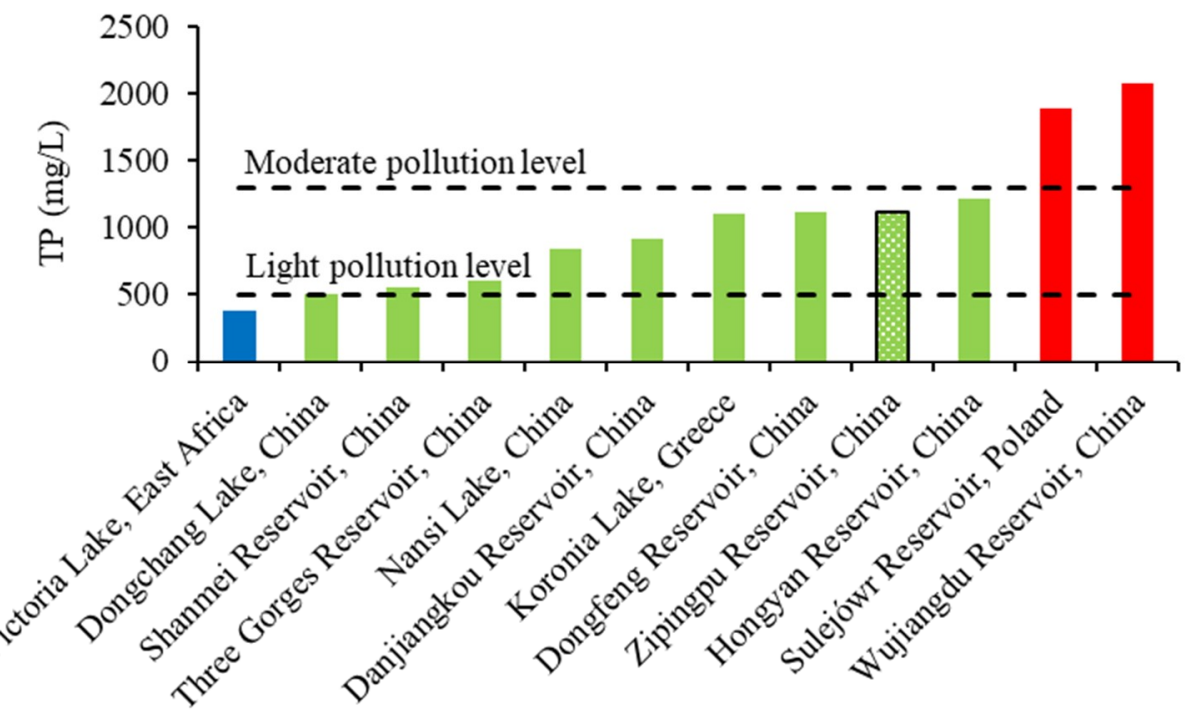

Figure 5. Sediment TP contents in different reservoirs and lakes.

The TP content significantly decreased from the tail to the front of Zipingpu Dam, except at sites G2 and G5. The TP content at G2 was slightly higher than that at G1. This difference is mainly caused by wastewater from Yingxiu, a county downstream of G2 that was reconstructed after being seriously damaged by the Wenchuan earthquake. Due to the Shouxi tributary, the TP content at G5 was significantly higher than that at G4.

The TP content can only reflect the accumulation of phosphorus in sediments and cannot directly show the release risk or biological stability. It is important to further analyze various forms of phosphorus in the sediments in the Zipingpu Reservoir. Different forms of phosphorus in sediments have different biochemical behaviors and bioavailabilities, and the potential influence of sediment on the water quality of overlying water cannot be ignored. Some phosphorus can be released from sediments and can be used by aquatic organisms; this fraction is defined as potential bioavailable phosphorus [39]. The water $\mathrm{pH}$ in the Zipingpu Reservoir was weakly alkaline, and Ex-P, Al-P, Fe-P, and OP in the Zipingpu Reservoir can be regarded as potential bioavailable phosphorus. As shown in Figure 6, the proportion of potential bioavailable phosphorus relative to TP in the Zipingpu Reservoir ranged from 8.53 (G3) to $18.45 \%$ (G4). The tail and middle of the reservoir had a relatively high content of potential bioavailable phosphorus, with values ranging from $76.15-244.20 \mathrm{mg} / \mathrm{kg}$. The potential bioavailable phosphorus in the Zipingpu Reservoir was present at a light pollution level. Under conditions typical of a weakly alkaline water body, the potential release risk of phosphorus in the surface sediments of the Zipingpu Reservoir was small. 


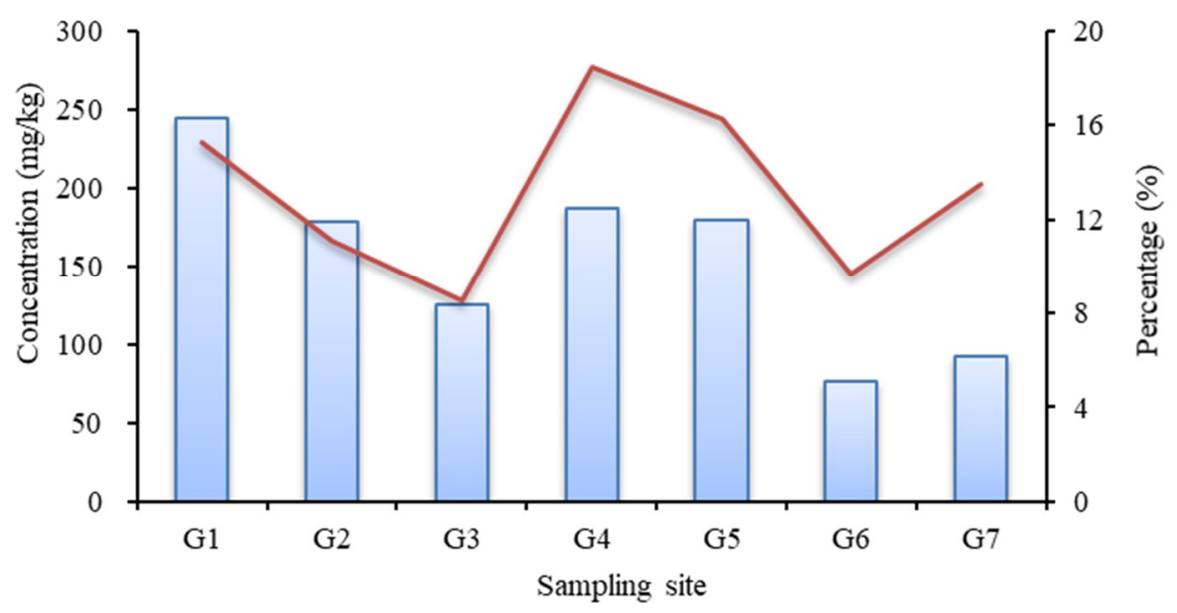

Figure 6. The concentration of potential bioavailable phosphorus (blue bars) and its proportion (red line) relative to TP in the Zipingpu Reservoir.

PP was the major form of phosphorus in overlying water in the Zipingpu Reservoir. Dynamic water conditions associated with reservoir operation were the main factors controlling phosphorus transport and subsidence. We speculate that some solid-phase phosphorus settled out with sediment particles before reaching the middle or front of the dam after entering the reservoir, which caused high concentrations of TP and PP at the tail of the reservoir.

\subsection{Exchange Characteristics of Phosphorus at the Sediment-Water Interface}

Reservoir sediment is an important material for the accumulation of nutrients. In addition to external sources (such as the surrounding environment and reservoir inflow), some sources are based on sediment exchange. Nutrients are released into the overlying water by convection and diffusion processes when the reservoir environment changes, which causes reservoir sediment to become a source of endogenous pollution.

Temperature had a significant influence on the exchange rate of phosphorus in the surface sediments of the Zipingpu Reservoir. At $5{ }^{\circ} \mathrm{C}$, the sediments in the river section, which had a neutral environment, and the reservoir section, which had an alkaline or neutral environment, existed in an absorption state, while sediments at $5{ }^{\circ} \mathrm{C}$ in other conditions existed in a release state. In all cases, all sediments showed a release state at a temperature of $9-19{ }^{\circ} \mathrm{C}$, and the release rate increased with increasing temperature.

\section{Conclusions}

Through the investigation of phosphorus in Zipingpu Reservoir and experiments investigating phosphorus exchange at the sediment-overlying water interface, the following distribution and release characteristics of phosphorus in reservoirs in southwest China can be drawn:

(1) The TP content of surface sediments in reservoirs decreased from the tail to the front of the dam, overall. The IP was the main form of phosphorus in surface sediments.

(2) PP was the main form of phosphorus in the overlying water of the reservoirs and was strongly affected by hydrodynamic conditions. The TDP content in the overlying water was relatively low.

(3) Both water temperature and $\mathrm{pH}$ significantly affected the release rate of the sediment, but the influence of water temperature was more significant. Acidic and alkaline conditions were conducive to the release of phosphorus from sediments, while a neutral environment was not. The release rate significantly increased with increasing water temperature. Sediment exhibited absorption characteristics when the water temperature was extremely low and releasing characteristics at a high temperature. 
Author Contributions: Conceptualization, Y.W., K.L. and Y.L.; Data curation, S.H.; Formal analysis, S.H.; Investigation, S.H.; Methodology, Y.W.; Software, Y.W. and R.L.; Writing—original draft, Y.W.; Writing一review and editing, K.L., R.L. and Y.L.

Funding: This work was sponsored by the National Key Project for Research and Development Plan (2016YFC0502210) and the National Natural Science Foundation of China (51479127).

Acknowledgments: We deeply appreciate the support on data analysis from Doctor Xunchi Pu.

Conflicts of Interest: The authors declare no conflict of interest.

\section{References}

1. López-Tarazón, J.A.; López, P.; Lobera, G.; Batalla, R.J. Suspended sediment, carbon and nitrogen transport in a regulated Pyrenean river. Sci. Total Environ. 2016, 540, 133-143. [CrossRef] [PubMed]

2. Maavara, T.; Parsons, C.T.; Ridenour, C.; Stojanovic, S.; Dürr, H.H.; Powley, H.R.; Van Cappellen, P. Global phosphorus retention by river damming. Proc. Natl. Acad. Sci. USA 2015, 112, 15603-15608. [CrossRef] [PubMed]

3. Lau, S.S.S.; Lane, S.N. Biological and chemical factors influencing shallow lake eutrophication: A long-term study. Sci. Total Environ. 2002, 288, 167-181. [CrossRef]

4. Conley, D.J.; Paerl, H.W.; Howarth, R.W.; Boesch, D.F.; Seitzinger, S.P.; Havens, K.E.; Likens, G.E. Controlling eutrophication: Nitrogen and phosphorus. Science 2009, 323, 1014-1015. [CrossRef] [PubMed]

5. Vink, S.; Chambers, R.M.; Smith, S.V. Distribution of phosphorus in sediments from Tomales Bay, California. Mar. Geol. 1997, 139, 157-179. [CrossRef]

6. Dong, L.; Yang, Z.; Liu, X. Phosphorus fractions, sorption characteristics, and its release in the sediments of Baiyangdian Lake, China. Environ. Monit. Assess. 2011, 179, 335-345. [CrossRef] [PubMed]

7. Ruttenberg, K.C. Development of a sequential extraction method for different forms of phosphorus in marine sediments. Limnol. Oceanogr. 1992, 37, 1460-1482. [CrossRef]

8. Filippelli, G.M.; Delaney, M.L. Phosphorus geochemistry of equatorial Pacific sediments. Geochim. Cosmochim. Acta 1996, 60, 1479-1495. [CrossRef]

9. Richerson, P.J.; Suchanek, T.H.; Why, S.J. The Causes and Control of Algal Blooms in Clear Lake: Clean Lakes Diagnostic/Feasibility Study for Clear Lake, California; University of California, Division of Environmental Studies: Santa Cruz, CA, USA, 1994.

10. Li, S. Internal phosphorus of Chagan Lake release and impact on eutrophication in low temperature period. Ph.D. Thesis, Jilin University, Changchun, China, 2013.

11. Kim, L.H.; Choi, E.; Gil, K.I.; Stenstrom, M.K. Phosphorus release rates from sediments and pollutant characteristics in Han River, Seoul, Korea. Sci. Total Environ. 2004, 321, 115-125. [CrossRef] [PubMed]

12. Wang, L.; Liang, T. Distribution characteristics of phosphorus in the sediments and overlying water of Poyang Lake. PLoS ONE 2015, 10, e125859. [CrossRef] [PubMed]

13. Huang, L.; Fang, H.; He, G.; Jiang, H.; Wang, C. Effects of internal loading on phosphorus distribution in the Taihu Lake driven by wind waves and lake currents. Environ. Pollut. 2016, 219, 760-773. [CrossRef] [PubMed]

14. Zhang, B.; Fang, F.; Guo, J.; Chen, Y.; Li, Z.; Guo, S. Phosphorus fractions and phosphate sorption-release characteristics relevant to the soil composition of water-level-fluctuating zone of Three Gorges Reservoir. Ecol. Eng. 2012, 40, 153-159. [CrossRef]

15. Jin, X.; He, Y.; Kirumba, G.; Hassan, Y.; Li, J. Phosphorus fractions and phosphate sorption-release characteristics of the sediment in the Yangtze River estuary reservoir. Ecol. Eng. 2013, 55, 62-66. [CrossRef]

16. Huang, H.; Yan, Z. Present situation and future prospect of hydropower in China. Renew. Sustain. Energy Rev. 2009, 13, 1652-1656. [CrossRef]

17. Fang, Y.; Deng, W. The critical scale and section management of cascade hydropower exploitation in Southwestern China. Energy 2011, 36, 5944-5953. [CrossRef]

18. Tang, X.J.; Zhou, J. A future role for cascade hydropower in the electricity system of China. Energy Policy 2012, 51, 358-363. [CrossRef]

19. Yong, X.D.; Tuo, Y.C.; Li, R.; Li, J.; Li, K.F.; Deng, Y.; Long, Q.J.; Teng, H. Deep water sampling system. Chinese Patent CN102128735A, 2010. 
20. Jin, X.; Tu, Q. Investigation Specification of Lake Eutrophication; China Environmental Science Press: Beijing, China, 1990.

21. Giblin, A.E.; Hopkinson, C.S.; Tucker, J. Benthic metabolism and nutrient cycling in Boston Harbor, Massachusetts. Estuaries 1997, 20, 346-364. [CrossRef]

22. Xu, Q.; Liu, X.; Wang, H.; Liu, L.; Liu, J. Study on the endogenous phosphorus load of sediments in Miyun reservoir. Sci. China Ser. D (Earth Sci.) 2005, 48, 333-340.

23. Jin, X.; Wang, S.; Pang, Y.; Wu, F.C. Phosphorus fractions and the effect of $\mathrm{pH}$ on the phosphorus release of the sediments from different trophic areas in Taihu Lake, China. Environ. Pollut. 2006, 139, 288-295. [CrossRef]

24. Peng, J.F.; Wang, B.Z.; Song, Y.H.; Yuan, P.; Liu, Z. Adsorption and release of phosphorus in the surface sediment of a wastewater stabilization pond. Ecol. Eng. 2007, 31, 92-97. [CrossRef]

25. Fan, C.X.; Zhang, L.; Bao, X.M.; You, B.S.; Zhong, J.C.; Wang, J.J.; Ding, S.M. Migration mechanism of biogenic elements and their quantification on the sediment-water Interface of Lake Taihu: II. Chemical thermodynamic mechanism of phosphorus release and its source-sink transiton. J. Lake Sci. 2006, 18, 207-217. (In Chinese)

26. Wang, Y.; Shen, Z.Y.; Hu, L.J.; Niu, J.F. Adsorption and release of phosphorus from sediments from the main branches of the Three-Gorges Reservoir. Acta Sci. Circumst. 2008, 28, 1654-1661. (In Chinese)

27. Yin, D.Q.; Qin, Q.R.; Yan, H. Effects of environmental factors on the release of phosphorus from sediments of Wuli Lake. J. Lake Sci. 1994, 6, 240-244. (In Chinese)

28. Andersen, F.Ø.; Ring, P. Comparison of phosphorus release from littoral and profundal sediments in a shallow, eutrophic lake. In Shallow Lakes' 98; Springer: Dordrecht, The Netherlands, 1999; pp. 175-183.

29. Ribeiro, D.C.; Martins, G.; Nogueira, R.; Cruz, J.V.; Brito, A.G. Phosphorus fractionation in volcanic lake sediments (Azores-Portugal). Chemosphere 2008, 70, 1256-1263. [CrossRef] [PubMed]

30. Hu, X.F. Study on Phosphorus Forms and Characteristics of Phosphorus Adsorption and Release of Sediments in Dongchang Lake. Master's Thesis, Ocean University of China, Qingdao, China, 2013.

31. Zhou, Z.M.; Shen, C.H.; Zhao, Z.L.; Tu, F. Distribution and pollution of total phosphorus and total nitrogen in surface sediments from Shanmei reservoir valley. J. Fuzhou Univ. 2011, 39, 608-612. (In Chinese)

32. Song, W.C. Polluted Characteristics Sediments and Phosphate Adsorption and Release Characteristics at the Sediment-Water Inerface in Nansi Lake, China, and Its Main Estuaries. Ph.D. Thesis, Shandong University, Changchun, China, 2008.

33. Wang, W.W.; Wang, S.H.; Zhao, L. Identification of inorganic and organic species of phosphorus and its bio-availability by aequential extraction method in surface sediments of Danjiangkou Reservoir. China Environ. Sci. 2016, 36, 808-818. (In Chinese)

34. Kaiserli, A.; Voutsa, D.; Samara, C. Phosphorus fractionation in lake sediments-Lakes Volvi and Koronia, N. Greece. Chemosphere 2002, 46, 1147-1155. [CrossRef]

35. Yin, R.; Wang, F.S.; Mei, H.Y.; Yao, C.C.; Guo, M.Y. Distribution of phosphorus forms in the sediments of cascade reservoirs with different trophic states in Wujiang catchment. Chin. J. Ecol. 2010, 1, 91-97. (In Chinese)

36. Frankowski, L.; Bolałek, J.; Szostek, A. Phosphorus in bottom sediments of pomeranian bay (Southern Baltic-Poland). Estuar. Coast. Shelf Sci. 2002, 54, 1027-1038. [CrossRef]

37. Owens, P.N.; Walling, D.E. The phosphorus content of fluvial sediment in rural and industrialized river basins. Water Res. 2002, 36, 685-701. [CrossRef]

38. Wang, S.; Jin, X.; Zhao, H.; Wu, F. Phosphorus fractions and its release in the sediments from the shallow lakes in the middle and lower reaches of Yangtze River area in China. Colloids Surf. A Physicochem. Eng. Aspects 2006, 273, 109-116. [CrossRef]

39. Dai, J.C.; Song, J.M.; Li, X.G.; Yuan, H.M.; Zheng, G.X.; Li, N. Sediment record of phosphorus and the primary study of its bioavailability in Jiaozhou Bay sediment. Environ. Sci. 2007, 28, 929-936. (In Chinese)

(C) 2019 by the authors. Licensee MDPI, Basel, Switzerland. This article is an open access article distributed under the terms and conditions of the Creative Commons Attribution (CC BY) license (http:/ / creativecommons.org/licenses/by/4.0/). 